\title{
First year growth in the lithodids Lithodes santolla and Paralomis granulosa reared at different temperatures
}

\author{
J.A. Calcagno ${ }^{\mathrm{a}, *}$, G.A. Lovrich $^{\mathrm{b}}$, S. Thatje ${ }^{\mathrm{c}}$, U. Nettelmann ${ }^{\mathrm{d}}$, K. Anger ${ }^{\mathrm{d}}$ \\ ${ }^{a}$ Universidad de Buenos Aires, Facultad de Ciencias Exactas y Naturales, Intendente Güiraldes 2160, Lab 64, 4to Piso, Pab II, \\ Cdad Universitaria C1428EHA, Buenos Aires, Argentina \\ ${ }^{\mathrm{b}}$ Consejo Nacional de Investigaciones Cientificas y Técnicas, Centro Austral de Investigaciones Científicas, CC 92, V9410BFD Ushuaia, \\ Tierra del Fuego, Argentina \\ ${ }^{\mathrm{c}}$ National Oceanography Centre, University of Southampton, European Way, Southampton S014 3ZH, UK \\ ${ }^{\mathrm{d}}$ Biologische Anstalt Helgoland, Stiftung Alfred Wegener Institute, Helgoland, Germany
}

Received 21 April 2005; accepted 21 April 2005

Available online 1 August 2005

\begin{abstract}
The southern king crab, Lithodes santolla Molina, and stone crab, Paralomis granulosa Jacquinot, inhabit the coldtemperate waters of southernmost South America (southern Chile and Argentina), where stocks of both species are endangered by overfishing. Recent investigations have shown that these crabs show life-cycle adaptations to scarcity of food and low temperatures prevailing in subantarctic regions, including complete lecithotrophy of all larval stages and prolonged periods of brooding and longevity. However, growth and development to maturity are slow under conditions of low temperatures, which may explain the particular vulnerability of subpolar lithodids to fisheries. In the present study, juvenile $L$. santolla and $P$. granulosa were individually reared in the laboratory at constant temperatures ranging from $3-15^{\circ} \mathrm{C}$, and rates of survival and development through successive instars were monitored throughout a period of about nine months from hatching. When the experiments were terminated, $L$. santolla had maximally reached juvenile instar IV (at $\left.6{ }^{\circ} \mathrm{C}\right), \mathrm{V}\left(9{ }^{\circ} \mathrm{C}\right)$, or VII $\left(15^{\circ} \mathrm{C}\right)$. In $P$. granulosa the maximum crab instar reached was II $\left(\right.$ at $\left.3{ }^{\circ} \mathrm{C}\right), \mathrm{V}\left(6{ }^{\circ} \mathrm{C}\right), \mathrm{V}\left(9{ }^{\circ} \mathrm{C}\right)$, or VII $\left(15{ }^{\circ} \mathrm{C}\right)$. The intermoult period decreased with increasing temperature, while it increased in successively later instars. In consequence, growth rate showed highly significant differences among temperatures $(\mathrm{P}<0.001)$. Growth-at-moult was highest at $9{ }^{\circ} \mathrm{C}$. Rates of survival decreased significantly in juvenile $P$. granulosa with increasing temperature. Only at $15{ }^{\circ} \mathrm{C}$ in $L$. santolla, was a significantly enhanced mortality found compared with lower temperatures. Our results indicate that juvenile stages of $L$. santolla and $P$. granulosa are well adapted to $5-10^{\circ} \mathrm{C}$, the range of temperatures typically prevailing in subantarctic marine environments. In spite of causing higher mortality rates, higher rearing temperatures $\left(12-15^{\circ} \mathrm{C}\right)$ should accelerate the rates of growth and maturation, which may be favourable for projects aiming at aquaculture or repopulation of overexploited king crab stocks.
\end{abstract}

(C) 2005 Elsevier B.V. All rights reserved.

Keywords: Lithodidae; Lithodes santolla; Paralomis granulosa; Temperature tolerance; Juvenile development; King crabs; Stone crabs

\footnotetext{
* Corresponding author.

E-mail address: javier@bg.fcen.uba.ar (J.A. Calcagno).
} 


\section{Introduction}

The family Lithodidae Samouelle, 1819, commonly known as 'king crabs' or 'stone crabs', presently consists of about 105 species (Dawson, 1989; Zaklan, 2002). This taxon shows a world-wide distribution, with a particularly high species diversity in high latitudes, but almost complete absence from the high polar seas (Thatje and Arntz, 2004). The vertical distribution of lithodids ranges from the shallow subtidal to the deep-sea basins (Zaklan, 2002). This family is considered to be one of the youngest higher taxa among the Decapoda, presumably originating from the intertidal zone of the northeastern Pacific (Makarov, 1962; Richter and Scholtz, 1994; Zaklan, 2001). According to Cunningham et al. (1992), the lithodids split approximately 13-25 million years ago from a hermit crab-like ancestor. However, the phylogenetic origin of the Lithodidae is still subject to controversy (see McLaughlin and Lemaitre, 1997, 2000; McLaughlin et al., 2001, 2003).

Lithodids are among the world's largest arthropods and have consequently received great attention by regional fisheries, in particular at high latitudes of both hemispheres (Dawson, 1989; Zaklan, 2002). In the southernmost parts of South America, the Magellan region in Chile and Argentina, lithodid crabs are also an important target for artisanal fisheries. In the Straits of Magellan and the Beagle Channel, the 'false king crab' or 'stone crab', Paralomis granulosa Jacquinot, and the 'southern king crab', Lithodes santolla Molina, have experienced collapsing stocks within a few decades of artisanal fisheries. After declining landings of $L$. santolla since the early 1980 s, local fisheries have partially or totally switched to P. granulosa. Due to its low growth rate, overfishing may lead to a similar impact in this species (Lovrich and Vinuesa, 1993, 1999; Lovrich, 1997).

The vulnerability of lithodid stocks in cold-temperate sub-polar environments is mainly due to low water temperatures in combination with short and strongly pulsed periods of planktonic food availability affecting in particular the early life-history stages. Due to slow growth, $P$. granulosa and L. santolla are estimated to require about 12 and 6 years, respectively, to reach maturity (Lovrich, 1997). In addition, the reproductive cycle is biennial and fecundity is low in $P$. granulosa (800-10,000 eggs per batch) as compared to L. santolla (5000-32,000 eggs per batch) which has an annual reproductive cycle (Lovrich, 1997). As an adaptation to the cold and food-limited pelagic environment in the Magellan region, both species have developed an abbreviated and completely lecithotrophic larval development (Calcagno et al., 2003; Kattner et al., 2003; Lovrich et al., 2003), which may be a general pattern in lithodid species from high latitudes (see Anger, 1996; Shirley and Zhou, 1997). Furthermore, previous studies on the early life history of $P$. granulosa and $L$. santolla showed that larvae of both species are cold-eurythermal. Larval development lasts from 24 days (at $15^{\circ} \mathrm{C}$ ) to almost four months (117 days, at $3{ }^{\circ} \mathrm{C}$ ), and from 19 days (at $15{ }^{\circ} \mathrm{C}$ ) to four months $\left(129\right.$ days, at $\left.3{ }^{\circ} \mathrm{C}\right)$, in P. granulosa and L. santolla, respectively (Anger et al., 2003, 2004).

Larval endotrophy makes artificial rearing relatively easy, so that it may also be feasible on a larger scale, allowing projects of mariculture and/or repopulating overexploited natural stocks to be carried out (Calcagno et al., 2004). In the present study, we present data on early juvenile growth of both species reared in the laboratory over a period of about 270 days after hatching under different temperature conditions. Differences in growth and survival are discussed from an ecological and biogeographic point of view, and their implications for aquaculture and/or restocking programmes are evaluated.

\section{Materials and methods}

Ovigerous females were collected from the Beagle Channel (Tierra del Fuego, southern Argentina; $\left.54^{\circ} 53.8^{\prime} \mathrm{S}, 68^{\circ} 17.0^{\prime} \mathrm{W}\right)$ using baited traps and local fishing boats (Lovrich, 1997; Lovrich et al., 2003) in April 2001. Subsequently, lithodid crabs were kept in submerged cages in the Beagle Channel, and later transported with the German research icebreaker 'Polarstern' to the marine biological laboratory at Helgoland, Germany (Biologische Anstalt Helgoland, BAH). Subsequently, the crabs were maintained in flow-through seawater aquaria at a constant $6{ }^{\circ} \mathrm{C}$, ca. 32 psu salinity, and a 12:12 h light:dark cycle.

Freshly hatched larvae were collected every morning from sieves receiving the overflowing water from 
Lithodes santolla

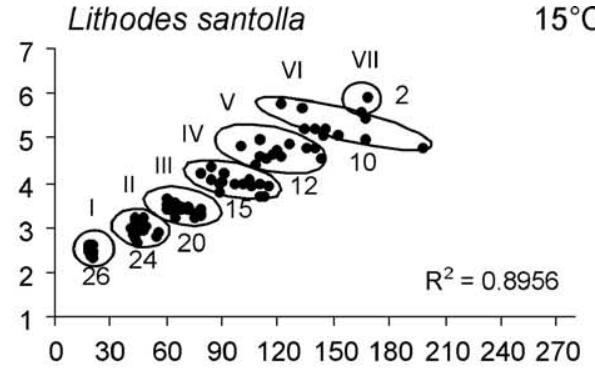

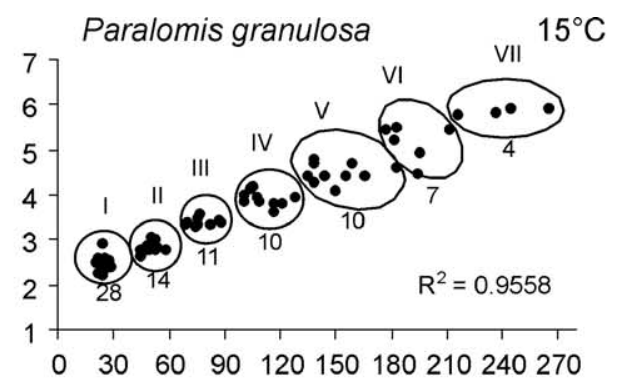
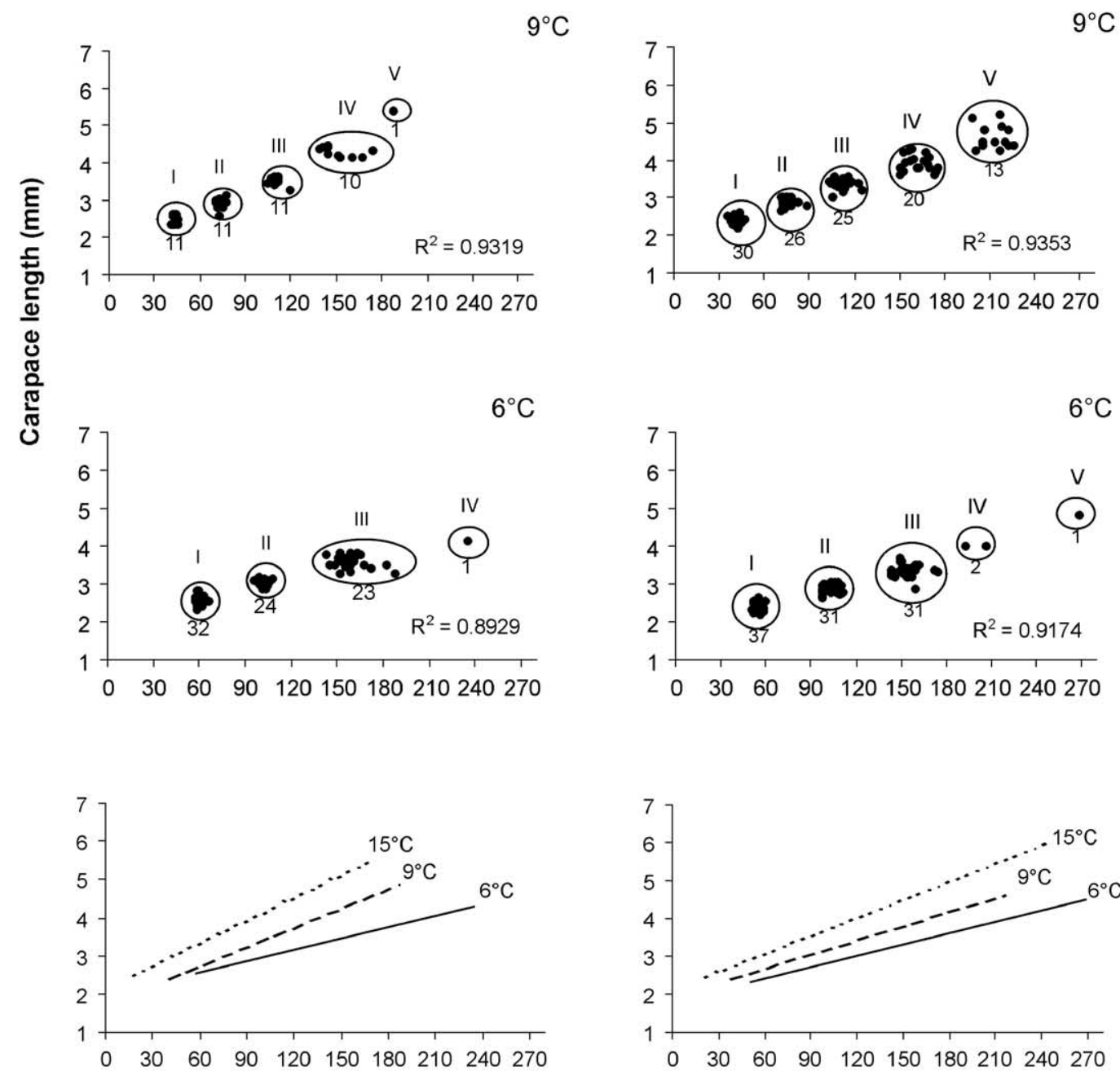

\section{Age (days)}

Fig. 1. Carapace length as a function of age at the time of moulting in the juvenile crab instars of Lithodes santolla and Paralomis granulosa. Circles enclose values for the same juvenile stage. Numbers below each circle indicate individuals of which size was available at each stage. Bottom panels show linear regressions whose parameters are in Table 1. 
aquaria with ovigerous females. The sieves were cleaned every evening to ensure that larval age did not vary by more than $12 \mathrm{~h}$. Actively swimming larvae obtained were isolated and reared in individual $100-\mathrm{ml}$ bowls kept in differently acclimated rooms, under the same conditions of salinity and light. The rearing experiments were conducted at temperatures of $6^{\circ}, 9^{\circ}$, and $15^{\circ} \mathrm{C}$ for about nine months.

Larvae were reared without food supply, as previous experiments (McLaughlin et al., 2001; Kattner et al., 2003; Lovrich et al., 2003) had shown that all larval stages of both Lithodes santolla and Paralomis granulosa are completely lecithotrophic. After metamorphosis, juvenile crabs were fed with Artemia nauplii (Argent Chemical Laboratories, USA) at an approximate concentration of 10 nauplii $/ \mathrm{ml}$. At $9^{\circ}$ and $15{ }^{\circ} \mathrm{C}$, the culture water and food were changed every day, and every third day at lower temperatures. In all treatments, larvae and crab instars were checked daily for moults or mortality. Exuviae were removed from flasks with a glass pipette of ca. $5 \mathrm{~mm}$ diameter. When crabs had moulted and exuviae was entire, carapace length $(\mathrm{CL})$ of the exuviae was measured to the nearest $0.01 \mathrm{~mm}$ from the base of the rostral spine to the posterolateral margin of the carapace using a Leica MZ8 stereomicroscope equipped with a calibrated eye piece micrometer. CL was the midline distance between posterior orbital margin, excluding the rostral spine, and the posterior median margin.

The total number of juvenile $L$. santolla obtained and subsequently reared at $6^{\circ}, 9^{\circ}$ and $15^{\circ} \mathrm{C}$ was 66 , 51, and 26, respectively. In P. granulosa, 74, 77, and 29 juveniles were initially available at $6^{\circ}, 9^{\circ}$ and 15 ${ }^{\circ} \mathrm{C}$, respectively. For each temperature and species, growth was described as growth rate, extension of the intermoult periods and with Hiatt diagrams. Growth rates were expressed as the linear function between increments in CL and time. Since intermoult is related with temperature, intermoult periods were expressed in degree-days. The degree-day intermoult period is the sum of temperatures during the intermoult period (Kurata, 1960; Stevens, 1990). Hiatt diagrams represent the linear function between pre-molt vs. postmoult CLs. In order to test for equality of growth rates (represented by slopes of linear regression lines) or growth at moult (represented by slopes of the Hiatt functions) at different temperatures, an ANCOVA followed by comparisons between pairs of slopes performed for each species (Sokal and Rohlf, 1995). Within each crab stage, the influence of temperature in the duration of the intermoult period was tested with a one-way ANOVA, and when significant differences were found, LSD post hoc contrasts were performed (Sokal and Rohlf, 1995).

For the different temperatures, survival was calculated as:

$\Sigma \mathrm{n}_{\mathrm{i}} \mathrm{d}_{\mathrm{i}} / \Sigma \mathrm{n}_{\mathrm{i}}$

where $n_{i}$ was the number of survived individuals on $i-$ day and $\mathrm{d}_{\mathrm{i}}$ was the age (in days) after larval hatching. Survival was calculated only for crabs that were measured. The differences among survival times at different temperatures were tested by means of a one-way ANOVA followed by comparisons between pairs of means (Sokal and Rohlf, 1995).

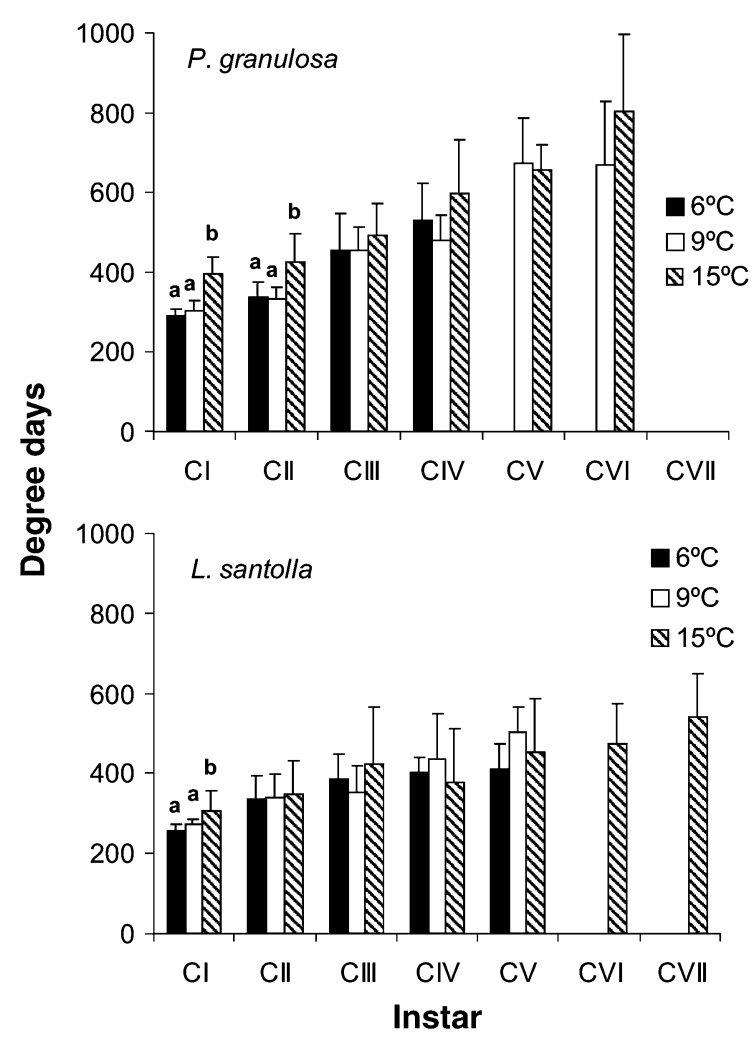

Fig. 2. Intermoult periods (in degree-days) +1 SD for each instar and temperature for Lithodes santolla (above) and Paralomis granulosa (below). Different letters denote significant differences $(p<0.01)$ in LSD post hoc comparisons. 


\section{Results}

\subsection{Growth and development}

For each species, the intermoult period increased with age (Figs. 1 and 2). In stage Crab I of Paralomis granulosa and Lithodes. santolla the intermoult period (in degree-days) was significantly longer with increasing temperature (Fig. 2). After stages Crab II P. granulosa and Crab III L. santolla, the intermoult was not influenced by the temperature (Fig. 2). For $L$. santolla as well as for P. granulosa, CL increased with age (Table 1, Fig. 1). The slopes of the equations of size vs. age, which represent the growth rate in $\mathrm{mm}$ per day, were highly significant (null hypothesis of slope $=0$, i.e. no growth rate) for all temperatures $(\mathrm{p}<0.001$; Table 1$)$. Coefficients of determination $\left(\mathrm{R}^{2}\right)$ varied between 0.89 and 0.95 (Table 1, Fig. 1). Increasing temperature significantly accelerated juvenile growth rate and decreased the intermoult period (Table 1, Fig. 1). In both L. santolla and P. granulosa, significant differences in mean CL (between adjacent means) and growth rates (slope comparisons) at $6^{\circ}, 9^{\circ}$, and $15{ }^{\circ} \mathrm{C}$ were detected $(\mathrm{P}<0.01$, for all temperatures). For each species, the intermoult period in- creased with age (Figs. 1 and 2). In $P$. granulosa the intermoult period at $15^{\circ} \mathrm{C}$ was always longer (Fig. 2), although significantly so only in stages Crab I.

In L. santolla, the moult increment was largest at $9^{\circ} \mathrm{C}$, illustrated by a significantly higher slope in the Hiatt function (Fig. 3; Table 2). Moult increments at different temperatures in $P$. granulosa exhibited a similar but non-significant tendency. (Fig. 3; Table 2).

\subsection{Survival}

Specimens died in the course of the experiment, which was terminated when all crabs died, at a maximum $270 \mathrm{~d}$ after hatching. Mortality of crabs of both species was strongly associated with moulting (c.f. Figs. 1 and 4). This was more evident at 6 and $9^{\circ} \mathrm{C}$ than at $15^{\circ} \mathrm{C}$, where mortality occurred continuously. This was probably because on the same date some animals were moulting to one stage, and others to the following stage (cf. Fig. 1 L. santolla at $15{ }^{\circ} \mathrm{C}$ ), depicting a continuous moulting occurrence. Since mortality was associated to moulting, the more molt events the higher probability of mortality. This was shown by a significantly shorter survival time with

Table 1

Growth of early juvenile stages of Paralomis granulosa and Lithodes santolla reared at different temperatures in the laboratory through the first year of life: maximum instar number attained within ca 270 days and maximum size in these instars

\begin{tabular}{|c|c|c|c|c|c|c|}
\hline & $\begin{array}{l}\text { Maximum } \\
\text { crab instar } \\
\text { attained }\end{array}$ & $\begin{array}{l}\text { Range date of } \\
\text { moulting to } \\
\text { maximum crab instar }\end{array}$ & $\begin{array}{l}\text { Mean CL }(\mathrm{mm}) \\
\text { at the maximum } \\
\text { measured instar }\end{array}$ & Growth vs time (T) & $\mathrm{R}^{2}$ & $\mathrm{P}$ \\
\hline \multicolumn{7}{|c|}{ Paralomis granulosa } \\
\hline $15^{\circ} \mathrm{C}$ & C VII & 5 Apr-24 Мay & 5.86 (VII) & $\mathrm{CL}=0.0159 \mathrm{~T}+2.1$ & 0.9558 & $<0.001$ \\
\hline $9{ }^{\circ} \mathrm{C}$ & C VII & 8 Jul-23 Aug & $4.61(\mathrm{~V})$ & $\mathrm{CL}=0.0126 \mathrm{~T}+1.91$ & 0.9353 & $<0.001$ \\
\hline \multirow[t]{4}{*}{$6{ }^{\circ} \mathrm{C}$} & C VI & 22 Aug-31 Aug & $4.00(\mathrm{~V})$ & $\begin{array}{l}\mathrm{CL}=0.0099 \mathrm{~T}+1.84 \\
\text { Slope comparisons }\end{array}$ & 0.9174 & $<0.001$ \\
\hline & & & & $\mathrm{H}_{\mathrm{o}}: 9{ }^{\circ} \mathrm{C}=6{ }^{\circ} \mathrm{C}$ & & $<0.01$ \\
\hline & & & & $\mathrm{H}_{\mathrm{o}}: 9{ }^{\circ} \mathrm{C}=15^{\circ} \mathrm{C}$ & & $<0.01$ \\
\hline & & & & $\mathrm{H}_{\mathrm{o}}: 6{ }^{\circ} \mathrm{C}=15{ }^{\circ} \mathrm{C}$ & & $<0.01$ \\
\hline \multicolumn{7}{|c|}{ Lithodes santolla } \\
\hline $15^{\circ} \mathrm{C}$ & C XIX & 15 May-7 Jul & 5.71 (VII) & $\mathrm{CL}=0.0199+2.12$ & 0.8956 & $<0.001$ \\
\hline $9{ }^{\circ} \mathrm{C}$ & C VII & 13 Jun-25 Aug & $5.40(\mathrm{~V})$ & $\mathrm{CL}=0.0168 \mathrm{~T}+1.72$ & 0.9319 & $<0.001$ \\
\hline \multirow[t]{5}{*}{$6{ }^{\circ} \mathrm{C}$} & C VI & 26 Jul-30 Aug & $4.12(\mathrm{~V})$ & $\mathrm{CL}=0.0099 \mathrm{~T}+1.99$ & 0.8929 & $<0.001$ \\
\hline & & & & Slope comparisons & & \\
\hline & & & & $\mathrm{H}_{\mathrm{o}}: 9{ }^{\circ} \mathrm{C}=6{ }^{\circ} \mathrm{C}$ & & $<0.01$ \\
\hline & & & & $\mathrm{H}_{\mathrm{o}}: 9{ }^{\circ} \mathrm{C}=15{ }^{\circ} \mathrm{C}$ & & $<0.01$ \\
\hline & & & & $\mathrm{H}_{\mathrm{o}}: 6{ }^{\circ} \mathrm{C}=15{ }^{\circ} \mathrm{C}$ & & $<0.01$ \\
\hline
\end{tabular}

Estimated growth rate is expressed as size, $\mathrm{CL}$ as a function of time, $\mathrm{T}$; $\mathrm{P}$ : probability that $\mathrm{H}_{\mathrm{o}}$ is true; $\mathrm{R}^{2}=$ coefficient of determination. 

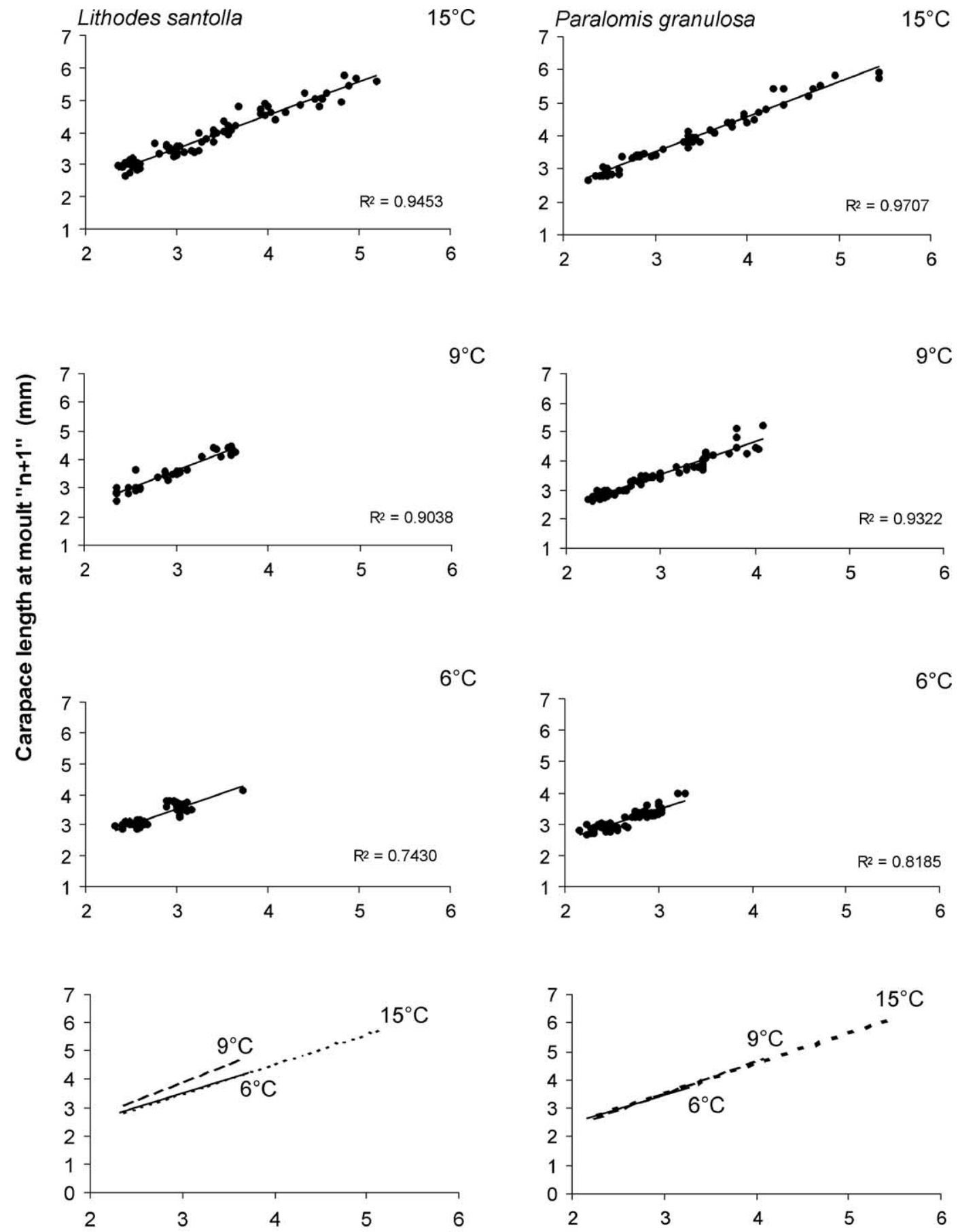

Carapace length at moult " $n$ "

Fig. 3. Scatterplots of postmoult size on premoult size (Hiatt diagrams) and fitted linear functions for the different rearing temperatures during the juvenile development of the lithodid crabs Lithodes santolla and Paralomis granulosa. Parameters of the linear functions are found in Table 2. 
Table 2

Paralomis granulosa and Lithodes santolla. Functions that describe young-of-the-year growth at different temperatures

\begin{tabular}{llllc}
\hline \multicolumn{2}{c}{ Hiatt function } & $\mathrm{n}$ & $\mathrm{R}^{2}$ & $\mathrm{P}$ \\
\hline Paralomis granulosa & & & \\
$15{ }^{\circ} \mathrm{C}$ & $\mathrm{CL}_{\mathrm{n}+1}=1.0724 \mathrm{CL}_{\mathrm{n}}+0.28$ & 54 & 0.9707 & $<0.001$ \\
$9{ }^{\circ} \mathrm{C}$ & $\mathrm{CL}_{\mathrm{n}+1}=1.1406 \mathrm{CL}_{\mathrm{n}}+0.11$ & 77 & 0.9322 & $<0.001$ \\
$6{ }^{\circ} \mathrm{C} \quad \mathrm{CL}_{\mathrm{n}+1}=0.9940 \mathrm{CL}_{\mathrm{n}}+0.50$ & 60 & 0.8185 & $<0.001$ \\
& $\mathrm{H}_{\mathrm{o}}: 15{ }^{\circ} \mathrm{C}=9{ }^{\circ} \mathrm{C}=6{ }^{\circ} \mathrm{C}$ & & & 0.1052 \\
& & & \\
Lithodes & santolla & & & \\
$15{ }^{\circ} \mathrm{C} \quad \mathrm{CL}_{\mathrm{n}+1}=1.0386 \mathrm{CL}_{\mathrm{n}}+0.38$ & 75 & 0.9453 & $<0.001$ \\
$9{ }^{\circ} \mathrm{C} \quad \mathrm{CL}_{\mathrm{n}+1}=1.2464 \mathrm{CL}_{\mathrm{n}}+0.14$ & 31 & 0.9038 & $<0.001$ \\
$6{ }^{\circ} \mathrm{C} \quad \mathrm{CL}_{\mathrm{n}+1}=1.0064 \mathrm{CL}_{\mathrm{n}}+0.20$ & 44 & 0.7430 & $<0.001$ \\
& $\mathrm{H}_{\mathrm{o}}: 15^{\circ} \mathrm{C}=9{ }^{\circ} \mathrm{C}=6{ }^{\circ} \mathrm{C}$ & & & 0.038 \\
& $\mathrm{H}_{\mathrm{o}}: 9{ }^{\circ} \mathrm{C}=6{ }^{\circ} \mathrm{C}$ & & & $<0.01$ \\
& $\mathrm{H}_{\mathrm{o}}: 9{ }^{\circ} \mathrm{C}=15{ }^{\circ} \mathrm{C}$ & & & $<0.01$ \\
& $\mathrm{H}_{\mathrm{o}}: 6{ }^{\circ} \mathrm{C}=15{ }^{\circ} \mathrm{C}$ & & & $>0.10$ \\
\hline
\end{tabular}

$\mathrm{CL}_{\mathrm{n}}$ : premoult carapace length; $\mathrm{CL}_{\mathrm{n}+1}$ : postmoult carapace length; $\mathrm{n}$ : number of moulting animals; $\mathrm{R}^{2}$ : coefficient of determination; $\mathrm{P}$ : probability that $\mathrm{H}_{\mathrm{o}}$ is true.

increasing temperature (Table 3). In P. granulosa, the survival time was significantly longer at $6{ }^{\circ} \mathrm{C}$ than at 9 and $15{ }^{\circ} \mathrm{C}$, whereas in L. santolla the significantly shortest survival time was at $15{ }^{\circ} \mathrm{C}$ (Table 3 ).

In L. santolla, the measured survivors had maximally reached juvenile instar IV $\left(6{ }^{\circ} \mathrm{C}\right), \mathrm{V}\left(9^{\circ} \mathrm{C}\right)$, and VII $\left(15{ }^{\circ} \mathrm{C}\right)$ (Fig. 4, Table 1), whereas in P. granulosa the maximum crab instar reached was $\mathrm{V}\left(6\right.$ and $\left.9{ }^{\circ} \mathrm{C}\right)$, and VII $\left(15^{\circ} \mathrm{C}\right)$ (Fig. 4, Table 1). Table 1 also shows the maximum crab instar attained, although not measured, and the range date of moulting to this instar.

\section{Discussion}

Lithodids or king crabs belong to the largest known arthropods, and are also considered top predators in food webs of benthic sublittoral and deepsea communities world-wide, in particular at high latitudes of both hemispheres (Dawson, 1989; Zaklan, 2002; Thatje et al., 2005). As a consequence, they are regionally of great economic value as a fishery resource, and there has thus been considerable interest in their commercial aquaculture and stock enhancement (see Konishi, 1998; Konishi and Shikatani, 1999; Stevens, 2003). However, attempts of artificial rearing have had very limited success, especially because our knowledge of the early life history, development, and growth of king crabs is still insufficient (Zaklan, 2002). Such knowledge is crucial not only for the development of economically feasible aquaculture techniques, but also for resource management of overexploited and regionally collapsing populations (Dawson, 1989; Lovrich, 1997; Zaklan, 2002).

The subantarctic lithodid crabs Lithodes santolla and Paralomis granulosa, which occur at high densities and show a centre of geographic distribution in the cold-temperate Magellan region around the southernmost tip of South America, represent a typical example for the vulnerability of exploited stocks in cold waters (Lovrich and Vinuesa, 1996; Lovrich, 1997). Compared to other commercially exploited Lithodidae, the early life history of these species has recently become quite well known. Their larvae are gradually released over extended hatching periods starting in the southern winter (Thatje et al., 2003), subsequently passing through three or four larval stages (Campodonico, 1971; Campodonico and Guzman, 1981; McLaughlin et al., 2001, 2003; Calcagno et al., 2004), and this abbreviated larval development is completely lecithotrophic from hatching until metamorphosis (Calcagno et al., 2003; Kattner et al., 2003; Lovrich et al., 2003). The food-independent mode of development renders larval rearing in both species relatively easy, which may also favour future aquaculture projects on a larger scale (for methodological discussion, see Calcagno et al., 2004). Moreover, a wide thermal tolerance window for successful development through metamorphosis $\left(3-15{ }^{\circ} \mathrm{C}\right.$ and $6-15$ ${ }^{\circ} \mathrm{C}$ in P. granulosa and L. santolla, respectively) indicates that the early life-history stages of these species are cold-eurythermal, which may further facilitate the artificial rearing under flow-through conditions with natural seawater at ambient temperatures (Anger et al., 2003, 2004).

The temperature-dependent patterns of juvenile mortality and growth observed during the first year of postlarval life are similar to those found in the larval development of both species (Nakanishi, 1985; Anger, 1996; Anger et al., 2003, 2004). Juvenile growth increases with temperature, while the intermoult period in successively later instars tends to increase. In P. granulosa, highest survival rates at 6 ${ }^{\circ} \mathrm{C}$ and $9{ }^{\circ} \mathrm{C}$ coincide with the temperature optima observed in larval development (Anger et al., 2003). 

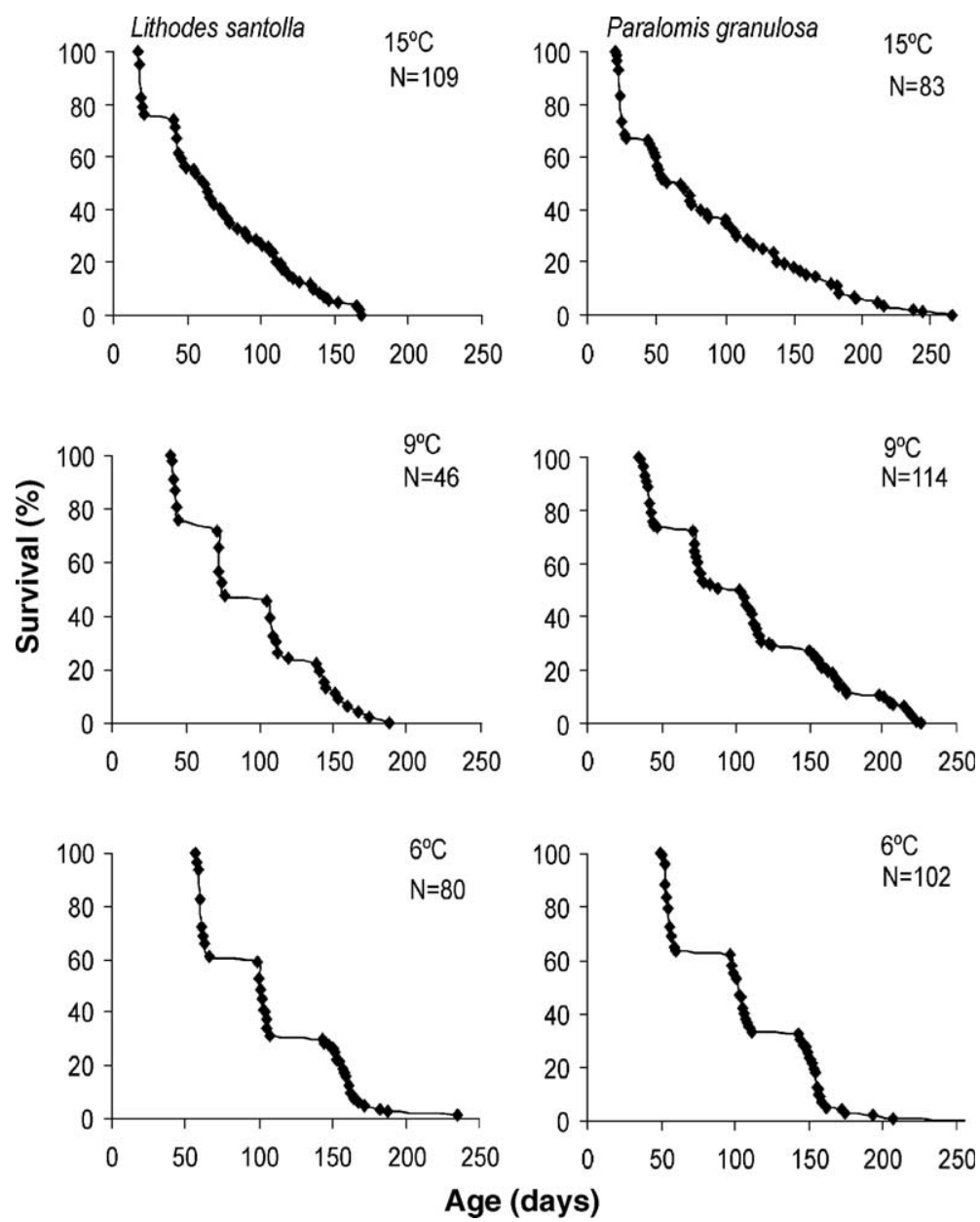

Fig. 4. Percentage of survival as a function of age in the juvenile instars of Lithodes santolla and Paralomis granulosa. N corresponds to the initial number of specimens available at the beginning of the juvenile phase.

A similar pattern has also been observed in L. santolla, which appears to be better adapted to a slightly higher temperature level $\left(9-12{ }^{\circ} \mathrm{C}\right)$, while it does not

Table 3

Average survival times (in days) of young-of-the-year Paralomis granulosa and Lithodes santolla reared at 6,9 , and $15{ }^{\circ} \mathrm{C}$

\begin{tabular}{lll}
\hline Temperature & \multicolumn{2}{l}{ Survival \pm 1 SD (days) } \\
\cline { 2 - 3 } & Paralomis granulosa & Lithodes santolla \\
\hline $6{ }^{\circ} \mathrm{C}$ & $242.6 \pm 68.5^{\mathrm{a}}$ & $207.1 \pm 94.6^{\mathrm{a}}$ \\
$9{ }^{\circ} \mathrm{C}$ & $191.3 \pm 97.4^{\mathrm{b}}$ & $198.4 \pm 103.6^{\mathrm{a}}$ \\
$15{ }^{\circ} \mathrm{C}$ & $140.0 \pm 77.7^{\mathrm{b}}$ & $117.8 \pm 73.8^{\mathrm{b}}$ \\
\hline
\end{tabular}

Values are shown with \pm 1 SD. Different letters mean significant differences among survival times for each species after an ANOVA and Scheffé's unplanned contrasts among means $(P<0.05)$. tolerate very low temperatures of $\leq 3{ }^{\circ} \mathrm{C}$ (Anger et al., 2004).

Since moults are crucial events in the development of crustaceans, and increased temperatures enhance the number of instars passed during early juvenile development, thermal stress at ecdysis may cause increased selection pressure on juveniles. Moreover, growth rates are higher at $9{ }^{\circ} \mathrm{C}$, probably indicating a physiological optimum. In his paper on juvenile growth in Paralithodes camtschaticus from the Bering Sea, Stevens (1990) and Stevens and Munk (1990) suggested that differences in growth rates observed in the field may reflect variability in temperatures among habitats, so that a growth model predicted that age at maturity varies with 
ambient water temperatures. L. santolla, which is distributed along the Pacific coast over approximately $13^{\circ}$ latitude and in the Atlantic over approximately $20^{\circ}$ (Retamal, 1981; Vinuesa, 1991; Boschi et al., 1992; Gorny, 1999), experiences regional differences in average seawater temperature of up to about $9{ }^{\circ} \mathrm{C}$ (Anger et al., 2004). Based on our present data on the temperature dependence of juvenile growth in L. santolla and P. granulosa, and considering the wide latitudinal range of distribution in both species (see Boschi et al., 1992; Anger et al., 2003, 2004), we can also conclude that variations in size at maturity among regional populations can be attributed to temperature dependence of growth. For example, female $L$. santolla attain sexual maturity at 67.5 and $75 \mathrm{~mm} \mathrm{CL}$ in the Golfo San Jorge (ca. $46^{\circ} \mathrm{S}$ ) and the Beagle Channel (ca. $55^{\circ} \mathrm{S}$ ), respectively (Vinuesa, 1984, 1985). Since our present data of juvenile growth still follow a linear pattern after about nine months of juvenile development (Fig. 1), an extrapolation of age at maturity based on these data is not possible. However, in both species significant growth differences at different rearing temperatures support Stevens' (1990) conclusion of temperature-dependent variability of age at maturity. This may have consequences for fishery management of cold-water species, in particular those with slow growth and long generation times. On the other hand, this pattern, in combination with larval endotrophy and euythermality, may be favourable for future aquaculture or restocking programmes.

\section{Acknowledgements}

We greatly appreciate the help of the crew of PFS 'Polarstern' during the transport of live king crabs from South America to Germany. Javier A. Calcagno is indebted to the German Academic Exchange Service (DAAD) for funding his research visit to Helgoland. This project was funded by the International Bureau of the German Ministry of Research (BMBF, project No. ARG 99/002), and the Argentine Secretaría Nacional para la Ciencia Tecnología e Innovación Productiva (SECyT). Partial additional support was provided by funds of a grant (PICT 01-10042) from the SECyT.

\section{References}

Anger, K., 1996. Physiological and biochemical changes during lecithotrophic larval development and early juvenile growth in the northern stone crab, Lithodes maja (Decapoda: Anomura). Mar. Biol. 126, 283-296.

Anger, K., Thatje, S., Lovrich, G., Calcagno, J., 2003. Larval and early juvenile development of Paralomis granulosa reared at different temperatures: tolerance of cold and food limitation in a lithodid crab from high latitudes. Mar. Ecol. Prog. Ser. 253, $243-251$.

Anger, K., Lovrich, G., Thatje, S., Calcagno, J., 2004. Larval and early juvenile development of Lithodes santolla (Molina, 1782) (Decapoda: Anomura: Lithodidae) reared at different temperatures in the laboratory. J. Exp. Mar. Biol. Ecol. 306, 217-230.

Boschi, E.E., Fischbach, C.E., Iorio, M.I., 1992. Catálago ilustrado de los crustáceos estomatópodos y decápodos marinos de Argentina. Frente Maritimo, Uruguay 10, 7-94.

Calcagno, J.A., Thatje, S., Anger, K., Lovrich, G.A., Kaffenberger, A., 2003. Changes in biomass and chemical composition during lecithotrophic larval development of the southern stone crab Paralomis granulosa. Mar. Ecol. Prog. Ser. 257, 189-196.

Calcagno, J.A., Anger, K., Lovrich, G.A., Thatje, S., Kaffenberger, A., 2004. Larval development of the subantarctic king crabs Lithodes santolla and Paralomis granulosa reared in the laboratory. Helgol. Mar. Res. 58, 11-14.

Campodonico, G.I., 1971. Desarrollo larval de la centolla Lithodes antarctica Jacquinot en condiciones de laboratorio (Crustacea Decapoda, Anomura: Lithodidae). An. Inst. Patagonia Punta Arenas 2, 181-190.

Campodonico, G.I., Guzman, L., 1981. Larval development of Paralomis granulosa (Jacquinot) under laboratory conditions (Decapoda, Anomura, Lithodidae). Crustaceana 40, 272-285.

Cunningham, C.W., Blackstone, N.W., Buss, L.W., 1992. Evolution of king crabs from hermit crab ancestors. Nature 355, 539-542.

Dawson, E.W., 1989. King crabs of the world (Crustacea: Lithodidae) and their fisheries: a comprehensive bibliography. Misc. Publ., vol. 101. New Zealand Oceanographic Institute, Wellington, New Zealand, pp. 1-338.

Gorny, M., 1999. On the biogeography and ecology of the Southern Ocean decapod fauna. Sci. Mar. 63 (Suppl. 1), 367-382.

Kattner, G., Graeve, M., Calcagno, J.A., Lovrich, G.A., Thatje, S., Anger, K., 2003. Lipid, fatty acid and protein utilization during lecithotrophic larval development of Lithodes santolla (Molina) and Paralomis granulosa (Jacquinot). J. Exp. Mar. Biol. Ecol. 292, 61-74.

Konishi, K., 1998. Production of juveniles of shrimps and crabs in Japan. Farming Japan 32, 28-37.

Konishi, K., Shikatani, N., 1999. Identification manual for larvae of commercially important crabs in Japan: II. Anomuran crabs. Bull. Natl. Res. Inst. Aquacul. 28, 5-13.

Kurata, H., 1960. Studies on the larvae and postlarvae of Paralithodes camtschaticus: III. The influence of temperature and salinity on the survival and growth of the larvae. Bull. Hokkaido Region. Fish. Res. Lab. 21, 9-14.

Lovrich, G.A., 1997. La pesquería mixta de las centollas Lithodes santolla y Paralomis granulosa (Anomura: Lithodi- 
dae) en Tierra del Fuego, Argentina. Invest. Mar. Valparaíso $25,41-57$.

Lovrich, G.A., Vinuesa, J.H., 1993. Reproductive biology of the false southern king crab (Paralomis granulosa, Lithodidae) in the Beagle Channel, Argentina. Fish. Bull. 91, 664-675.

Lovrich, G.A., Vinuesa, J.H., 1996. Reproductive strategies of two lithodids in the Beagle Channel, Argentina: a complementary management tool in a changing fishery. High Latitude Crabs: Biology, Managament, and Economics. Alaska Sea Grant College Program 1996, 333-340.

Lovrich, G.A., Vinuesa, J.H., 1999. Reproductive potential of the lithodids Lithodes santolla and Paralomis granulosa (Anomura, Decapoda) in the Beagle Channel. Argentina. Sci. Mar. 63 (Suppl. 1), 355-360.

Lovrich, G.A., Thatje, S., Calcagno, J.A., Anger, K., Kaffenberger, A., 2003. Changes in biomass and chemical composition during lecithotrophic larval development of the southern king crab, Lithodes santolla (Molina). J. Exp. Mar. Biol. Ecol. 288, $65-79$.

Makarov, R.R., 1962. Fauna of U.S.S.R. (Crustacea). In: Shtakelberg, A.A. (Ed.), Israel Prog. Sci. Translat., Jerusalem, pp. $1-283$.

McLaughlin, P.A., Lemaitre, R., 1997. Carcinization in the Anomura-fact or fiction? I. Evidence from adult morphology. Contrib. Zool. 67, 79-123.

McLaughlin, P.A., Lemaitre, R., 2000. Aspects of evolution in the anomuran superfamily Paguroidea: one larval perspective. Inv. Reprod. Devel. 38, 159-169.

McLaughlin, P.A., Anger, K., Kaffenberger, A., Lovrich, G.A., 2001. Megalopal and early juvenile development in Lithodes santolla (Molina, 1782) (Decapoda: Anomura; Paguroidea: Lithodidae), with notes on zoeal variations. Inv. Reprod. Devel. 40, 53-67.

McLaughlin, P.A., Anger, K., Kaffenberger, A., Lovrich, G.A., 2003. Larval and early juvenile development in Paralomis granulosa (Jacquinot) (Decapoda: Anomura: Paguroidea: Lithodidae), with emphasis on abdominal changes in megalopal and crab stages. J. Nat. Hist. 37, 1433-1452.

Nakanishi, T., 1985. The effects of the environment on the survival rate, growth and respiration of eggs, larvae and post-larvae of king crab (Paralithodes camtschatica). In: Melteff, B.R. (Ed.), Proc. Int. King Crab Symp., Lowell Wakefield Fisheries Symposium Series, Alaska Sea Grant Report, vol. 85-12. University of Alaska, Fairbanks, AK, pp. 167-185.

Retamal, M.A., 1981. Catálogo ilustrado de los Crustáceos Decápodos de Chile. Gayana. Zoología, vol. 44. Universidad De Concepción, Chile, pp. 1-110.

Richter, S., Scholtz, G., 1994. Morphological evidence for a hermit crab ancestry of lithodids (Crustacea, Decapoda, Anomura, Paguroidea). Zool. Anz. 233, 187-210.
Shirley, T.C., Zhou, S., 1997. Lecithotrophic development of the golden king crab Lithodes aequispinus (Anomura: Lithodidae). J. Crust. Biol. 17, 207-216.

Sokal, R.R., Rohlf, F.J., 1995. Biometry. Freeman and Co., New York, pp. 1-887.

Stevens, B., Munk, J., 1990. A temperature dependent model for juvenile red king crab, Paralithodes camtschaticus, in Kodiak, Alaska. In: Melteff, B.R. (Ed.), Proc. Int. Symp. King Tanner Crabs. Lowell Wakefield Fisheries Symposium Series, Alaska Sea Grant Report, vol. 90-04. University of Alaska, Fairbanks, AK, pp. 293-304.

Stevens, B.G., 1990. Temperature-dependent growth of juvenile red king crab (Paralithodes camtschatica) and its effects on size-atage and subsequent recruitment in the eastern Bering Sea. Can. J. Fish. Aquat. Sci. 47, 1307-1317.

Stevens, B.G., 2003. Settlement, substratum preference, and survival of red king crab Paralithodes camtschaticus (Tilesius, 1815) glaucothoe on natural substrata in the laboratory. J. Exp. Mar. Biol. Ecol. 283, 63-78.

Thatje, S., Arntz, W.E., 2004. Antarctic reptant decapods: more than a myth? Polar Biol. 27, 195-201.

Thatje, S., Calcagno, J.A., Lovrich, G.A., Sartoris, F.J., Anger, K., 2003. Extended hatching periods in the subantarctic lithodid crabs Lithodes santolla and Paralomis granulosa (Crustacea: Decapoda: Lithodidae). Helgol. Mar. Res. 57, 110-113.

Thatje, S., Anger, K., Calcagno, J.A., Lovrich, G.A., Pörtner, H.O., Arntz, W.E., 2005. Challenging the cold: crabs reconquer the Antarctic. Ecology 86, 619-625.

Vinuesa, J.H., 1984. Sistema reproductor, ciclo y madurez gonadal de la centolla (Lithodes antarcticus) del Canal Beagle. Contrib. INIDEP 441, 75-95.

Vinuesa, J.H., 1985. Differential aspects of the southern king crab (Lithodes antarcticus) in two latitudinally separated locations. Proc. Int. King Crab Symp. Univ. Alaska, Alaska Sea Grant Rep., vol. 85-12, pp. 267-279.

Vinuesa, J.H., 1991. Biología y pesquería de la centolla (Lithodes santolla). Atlantica 13, 233-244.

Zaklan, S.D., 2001. Evolution of the family Lithodidae (Crustacea, Anomura, Paguroidea). Ph.D. Thesis, University of Alberta, Edmonton, Alberta, Canada.

Zaklan, S.D., 2002. Review of the family Lithodidae (Crustacea: Anomura: Paguroidea): distribution, biology, and fisheries. In: Paul, A.J., Dawe, E.G., Elner, R., Jamieson, G.S., Kruse, G.H., Otto, R.S., Sainte-Marie, B., Shirley, T.C., Woodby, D. (Eds.), Crabs in Cold Water Regions: Biology, Management, and Economics. University of Alaska Sea Grant College Program AKSG-02-01, Fairbanks, AK, pp. 751-845. 